guidelines as laid down, for instance, in the scholarly work of Runyan (1982).

What is Schlesinger's own view of the creative person? She tells us (2002) that he/she is a heroic and mystical figure, branded as mad by the jealous and uncomprehending average person. This is a straightforward reiteration of the ideas of the antipsychiatry movement of the 1960s and 1970s. We are back in the realms of the Laingian figure who is simply too insightful and too existentially aware for our society. Have we not moved on since then?

Jamison, K. R. (1989) Mood disorders and patterns of creativity in British writers and artists. Psychiatry, $\mathbf{5 2}$ 125-134.

Jamison, K. R. (1993) Touched With Fire: Manic Depressive Illness and the Artistic Temperament. New York: Free Press.

Ludwig, A. M. (1995) The Price of Greatness: Resolving the Creativity and Madness Controversy. New York: Guilford Press.

Runyan, W. M. (1982) Life Histories and Psychobiography: Explorations in Theory and Method. New York: Oxford University Press.

Schlesinger, J. (2002) Issues in creativity and madness. Part two: eternal flames. Ethical Human Sciences and Services: An International Journal of Critical Inquiry. 4, 139-142.

G.Wills 13 Mile End Lane, Davenport, Stockport, Cheshire SK2 6BN, UK

\section{Creativity, mental disorder and jazz}

I am very happy that Poole (2003) feels that my paper (Wills, 2003) makes a significant contribution to the literature on the relationship between creativity and mental disorder. Nevertheless, I would like to comment on certain points that he makes.

First, the literature on the above topic may be flawed, but it is not small, since an abundance of references extends back at least a hundred years, and it is not inconclusive, since a regular finding is that of the connection between high artistic creativity and mood disorders.

Second, although jazz biographies are written in order to sell books, they tend to be sober, respectful and well-researched, and often are written by academics. Even the most comprehensive psychiatric assessment cannot match the time and effort expended by responsible biographers.

Poole feels that I was uncritical in my acceptance that Thelonious Monk had a dementing process caused by excessive drug usage. My information was taken from the biography by Gourse (1997).
She interviewed Dr Everett Dulit, a Monk afficionado who discussed Monk's case with doctors who knew him, and who felt that drug-induced dementia was the likely diagnosis. Similarly, Poole feels that John Coltrane did not necessarily exhibit pathological behaviours, yet first-person accounts in six Coltrane biographies describe these, and in his acclaimed biography Porter (1998) states, 'There is absolute agreement that Coltrane practiced maniacally....

Poole's belief that 'Even severe mental disorder is not incompatible with creativity...there is no negative association between the two' needs clarification. It depends on the type, and the stage of development of the mental disorder. For instance, hypomania often facilitates creativity, but severe depression will extinguish it (Akiskal \& Akiskal, 1988).

A better understanding of the link between creativity and mental disorder will help great artists to do what they do best - be creative.

Akiskal, H. S. \& Akiskal, K. (1988) Reassessing the prevalence of bipolar disorders: clinical significance and artistic creativity. Psychiatry and Psychobiology, 3 (suppl.) $29 s-36 s$

Gourse, L. (1997) Straight, No Chaser: The Life and Genius of Thelonious Monk. New York: Schirmer.

Poole, R. (2003) 'Kind of Blue': creativity, mental disorder and jazz. British Journal of Psychiatry, I83, 193-194.

Porter, L. (1998) John Coltrane: His Life and Work. Ann Arbor, MT: University of Michigan Press.

Wills, G. (2003) Forty lives in the bebop business: mental health in a group of eminent jazz musicians. British Journal of Psychiatry, 183, 255-259.

G.Wills 13 Mile End Lane, Davenport, Stockport Cheshire SK2 6BN, UK

\section{Flashbacks in war veterans}

Jones et al (2003b) appears to have missed the point of my letter (Burges Watson, 2003). They define flashbacks as 'a form of dissociative state' (Jones et al, 2003a). This is the way the term flashback is used in the DSM-IV; 'dissociative flashback episodes' (American Psychiatric Association, 1994). They appear as an example of one of five ways in which 'the traumatic event is persistently re-experienced'. Only one is necessary for the diagnosis. As such they are not 'a core symptom' of post-traumatic stress disorder. As defined in DSM-IV, flashbacks themselves are no more than 'a recurrence of a memory, feeling or perceptual experience from the past'. This definition may well have been introduced because of the popularity of the term 'flashback' and necessary because its original meaning had been changed by popular usage. Jones et al are probably right when they hypothesise that this popularity was encouraged by the use of flashbacks in films and television programmes.

The changing presentation of symptoms associated with the extreme stress of war is indeed interesting. Bizarre dissociative states with physical manifestations, while very common in the First World War, were comparatively rare in the Second World War and very uncommon in Vietnam veterans. Thus, in line with the focus on physical symptoms in earlier wars, it would seem that the presentation of dissociative states has also moved from the physical to the psychological.

American Psychiatric Association (1994) Diagnostic and Statistical Manual of Mental Disorders (4th edn) (DSM-IV). Washington, DC: APA.

Burges Watson, I. P. (2003) Flashbacks and PTSD (letter). British Journal of Psychiatry, 183, 75-76.

Jones, E., Vermaas, R. H., McCartney, H., et al (2003a) Flashbacks and post-traumatic stress disorder: the genesis of a 20th-century diagnosis. British Journal of Psychiatry, 182, 158-163.

Jones, E., Vermaas, R. H., Beech, C., et al (2003b) Flashbacks and PTSD: authors' reply (letter). British Journal of Psychiatry, 183, 76-77.

I. P. Burges Watson The Hobart Clinic, Rokeby, Tasmania, Australia 7019

\section{Mental health and social capitals}

The correspondence prompted by McKenzie et al's (2002) editorial suggests that social capital can be the property of individuals as well as groups (Pevalin, 2003; Walkup, 2003). However, McKenzie finds this idea problematic and argues that, as the majority of health scientists conceive of social capital as an ecological concept, we should 'consider effects at an individual level as social networks' (McKenzie, 2003: p. 458). This restricted view rejects the potential contribution to psychiatric research of alternative sociological conceptions of social capital that are both rigorously defined and empirically tested.

One such approach is taken by Lin et al (2001) who adopt neo-Marxist notions of capital. Here, social capital is 'investment in social relations by individuals through which they gain access to embedded resources to enhance expected returns of 